\title{
Çivili plak bulunduran hibrit bir implant sistemi
}

\author{
A hybrid implant system with a nailed plate
}

\author{
Mehmet Nuri Konya
}

Afyonkarahisar Sağlık Bilimleri Üniversitesi Tıp Fakültesi, Ortopedi ve Travmatoloji Ana Bilim Dalı, Afyonkarahisar

Bu buluş kemik kırıklarının tespitinde kırık hattı üstünde ve altında drilizasyon yapmaya gerek duymadan plağı kemiğe tespit etmeye yarayan çivili plak implant sistemi ile ilgilidir. Bu amaca ulaşılabilmesi amacıyla hem plak hem de " $U$ " formunda çivileri yapısında bulunduran hibrit bir implant sistemi oluşturulmuştur.

Anahtar sözcükler: $U$ çivisi; kırık; plak

\section{T. C. Türk Patent Enstitüsü'ne Patent Belgesi için Başvuru Bilgileri ${ }^{[1]}$}

Başvuru bilgileri Tablo 1'de gösterilmiştir. ${ }^{[1]}$

Tablo 1. Başvuru bilgileri[1]

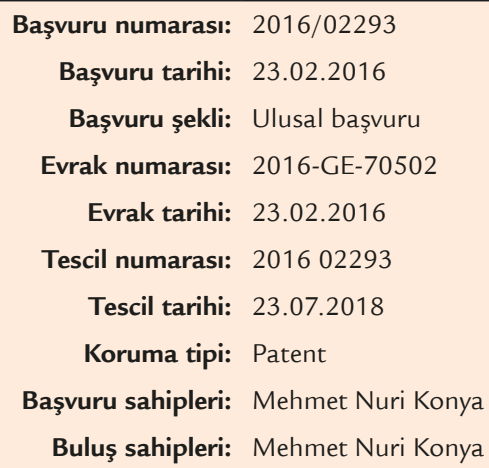

\section{FAYDALI MODEL BELGESI - No: TR 2016/02293 Y[1]}

\section{Teknik Alan ${ }^{[1]}$}

“Bu buluş kemik kırıklarının tespitinde kırık hattı üstünde ve altında drilizasyon yapmaya gerek duymadan plağı kemiğe tespit etmeye yarayan çivili plak implant sistemi ile ilgilidir. Bu amaca ulaşılabilmesi amacılla hem plak hem de "U" formunda çivileri yapısında bulunduran hibrit bir implant sistemi oluşturulmuştur."
The present invention relates to a U-nail plate implant system for fixing the plate to the bone without the need for drilization above and below the fracture line in the fixation of bone fractures. In order to achieve this goal, a hybrid implant system has been created that includes both plate and U-shaped nails.

Key words: U nail; fracture; plate

\section{Tekniğin Bilinen Durumu[1]}

"Kemik kırığı, kemik esnekliğini aşan direkt veya dolaylı travma nedeniyle kemik bütünlügünün bozulmasıdır. Kemiğin herhangi bir yerinde gelişebilir. Kırıklara neden olan başlıca sebepler: Trafik kazaları, düşme, çarpma, burkulma, ev içi kazalar, iş kazaları, spor kazaları ve yaralanmaları, üzerine cisim düşmesi, ateşli silah yaralanması gibi travmalardır. Kırığı oluşturan kuvvet sadece kemiği kırmayıp, beraberinde kemiğin etrafindaki yumuşak dokuları (deri, kaslar, tendon, bağları, damar ve sinirler) yaralayabilir.

Kemik kırıklarında tedavinin amacı, vücut bütünlügünün săglanırken fonksiyonun geri kazanılmasıdır. Temel olarak kemik kırıkları alçı ile tespit ya da cerrahi tespit yöntemleri kullanılarak tedavi edilirler. Cerrahi tespit yöntemleri implantları temel alan tedavi usulleridir.

Kırık tipine ve yerleşimine göre kullanılan implantın çeşitliliği değişmektedir.

Cerrahi tespit ve tedavi yöntemleri olarak kullanılan implantlardan bazıları şunlardır:

- Plak-vidalar (tıbbi çelik ve titanyum, kilitli)

- Intramedüller kilitli çiviler

- Tek tarafı veya çember şeklinde eksternal fiksatörler (ilizarov)

- Parsiyel/total kalça protezleri

- "U” çivileri

- İletişim adresi: Doç. Dr. Mehmet Nuri Konya, Afyonkarahisar Sağlık Bilimleri Üniversitesi, Zafer Külliyesi, D Blok No: 341, Afyonkarahisar Tel: 0505 - 8296019 e-posta: nurikonya@gmail.com ORCID iD: 0000-0002-5877-8347

- Geliș tarihi: 15 Kasım 2020 Kabul tarihi: 7 Aralık 2020 
Özellikle eklem içi parçalı kırıklar ve küçük kırık fragmanları nedeni ile plak ve vida kullanımı tercih edilen bir tedavi yaklaşımıdır. Her cerrahi yaklaşımda olduğu gibi plak ve vida ile tespitin de belli dezavantajları mevcuttur. Vida başında gevşeme veya yalama olması, vida kırılması, drilizasyon sırasında gelişebilecek termal nekroz, vida çıkarımı sonrası tekrar kırık oluşumu gibi komplikasyonlara neden olabilmektedir.

Plak-vida uygulamalarına örnek olarak verilebilecek, TR 2011/12190 sayılı faydalı model başvurusunda kilitli kompresyon plă̆ı, delik, kilitli vida ve yivli vidadan meydana gelen kilitli plaklarda kompresyon vida sistemi tarif edilmektedir. Vida başının yivli olması sayesinde, plak üzerindeki yivli deliklere sabitlenmesi ve dolayısı ile yükün plak üzerinden taşınmasını ve daha stabil bir tespit yapılabilmesi sağlanmaya çalısıılmıştır. Diğer taraftan iki parçalı vida tasarımı ile ana parça, içi delikli ve ucu yivli bir vidadır ve plak üzerine kilitlenebilmektedir. Ikinci parça ise yine bir vida şeklindedir ve ana vida ekseninde, zıt taraftan ve çektirilmek/kompresyon yapılmak istenen kemik parçasını geçerek, ana vida parçasının içerisine yivlenmekte ve sıkıştırıldıkça da iki kemik parçasının birleştirilmesi ve birleşim noktasının komprese olmasını sağlamaktadır.

Yaşlı hastalarda ise osteoporoza bağlı olarak artan kemik kırıklarında özellikle eklem hattına yakın kırıklarda ve sonrasında gelişen deformitelerin düzeltme ameliyatları sırasında plak vida tespiti önem arz etmektedir. Implant endüstrisinde gelişmelere rağmen vidalama tekniğinde çok fazla bir değişiklik olmamıştır.

Ortopedik bileşenler ve özellikle de intramedüller çiviler EP2349040 sayılı patent başvurusunda tarif edilmektedir.

Antirotasyon ve kompresyon yapma özelliği olan sefalik kompresif vida, femur çivisi, bahsedilen sefalik kompresif vidayı, femur çivisine sabitleyen ve tepe noktasından femur çivisine gönderilen tepe vidası ve kortikal vida içeren kalça eklemi bölgesindeki kırıkların (femur intertrokanterik, pertrokanterik ve subtrokanterik kırıklar vb.) tedavisinde, ortopedik implant olarak kullanılan proksimal femoral intramedüller çivi TR 2012/13856 sayılı faydalı model başvurusunda tarif edilmektedir.

"U" çivisi veya staple olarak adlandırılan tespit yöntemi özellikle kemik kırıklarının tespitine, tendonun kemiğe tespitinde, artrodez ameliyatlarında kullanılan bir tespit yöntemidir. Vida komplikasyonları içinde, kemikte drilizasyon sırasında ısı üretimine bağlı olarak termal nekroz oluşabilir. Kesi sırasında oluşan enerji boşalımı moleküller arası bağı bozabilir. ikinci negatif etkisi ise, kesilmeyen yüzlerde sürtünmeye bağlı olarak kan ve doku sıvilarına geçebilmesidir. Kemik dokusu ısıya karşı hassastır ve artmış ısı protein denatürasyonuna yol açarak hücre ölümüne neden olabilmektedir. Hücre ölümü sonrası enfeksiyon riski artmakta, aynı zamanda kemiğin mekanik gücü de azalmaktadır.
Vida gönderimi sırasında yüksek hızlı devirlerle kemik içine açılan deliklerden gönderilen vidalar kemikte termal nekroza neden olmaktadır. Kırık hattının kaynaması sonrasında implant çıkarımına bağı özellikle vida delikleri seviyesinde kırıklar oluştuğu görülmüştür. Ayrıca özellikle eklem çevresine yakın bölgelerde oluşan kırıklarda, gönderilen vida sayısııın sayısında sınırlılıklar nedeni ile stabilite yeterli seviyede sağlanamamakta veya gönderilen vidalar nedeni ile yeterli kemik dokusu kalamamaktadır. Bir diğer problem de osteoporozu olan yaşlı hastalarda görülmektedir. Osteoporozlu kemikte korteks medulla oranı azalmasına bağlı olarak vida ile tespitte yetersizlikler meydana gelmekte, vidalar kemikten slyrilabilmekte veya yeni kırıklar oluşabilmektedir.”

\section{Buluşun Çözümünü Amaçladığı Problemler ${ }^{[1]}$}

Buluşun amaci, termal nekrozu engelleyen plak tespitinin "U" çivisi ile fiksasyonu sağlayan yeni bir implant yapısı oluşturmaktır.

Bu buluşun amacı, çok sayıda küçük çivinin yerleştirilmesine izin vererek fiksasyonun stabilitesini artıran ve ameliyat süresini kısaltabilen ortopedik implant yapılanması ortaya koymaktır.

Buluşun bir başka amacı, farklı plak formları ile uygulanması düşünülen bölgenin anatomisine göre dizayn edilebilecek yapılanmalar oluşturmaya müsait ortopedik implant yapılanması ortaya koymaktır.

Buluşun bir diğer amacı, termal nekrozun etkilerinin minimale indirilerek önceden belirtilen komplikasyonların engellemek ve çok kısa fragmanlarda dahi plak ile tespitin mümkün olan en fazla sayıda vida ile tespitinin sağlanmasına uygun implant yapılanması ortaya koymaktır.

\section{Buluşun Açıklanması ${ }^{[1]}$}

Şekillerdeki referansların açıklaması [1]; (1) Plak gövdesi, (2) Delik, (3) Vida deliği, (4) "U” çivisi, (4.1) Çivi kolu, (5) Çivi, (5.1) Çivi kolu.

Buluş; üzerinde, fiksasyon sırasında kemiğe tespit edilebilmesi amacıyla en az iki çivi kolu bulunan çivinin (5) montajina uygun yapıda en az iki sıra halinde delikler (2) bulunduran plak gövdesidir (1).

Şekil 1'de daha geniş delikler (2) bulunduran plak gövdesi (1) yapılanması gösterilmiştir. Deliklerin (2) daha geniş hale getirilebilmesi için, delikler (2) kanal formunda tasarlanmıştır.

Şekil 1'de tarif edilen geniş delikler (2) bulunduran plaka gövdesi (1) yapılanması özellikle femur, tibia ve humerus gibi büyük kemiklerin fiksasyonu amacılla kullanılabilmektedir.

Şekil 2'de verilen plak gövdesi (1) de üzerinde dar delikler (2) bulundurur. Delikler (2) orta kısmında ise vida delikleri (3) bulundurmaktadır. Vida deliklerinden (3), vidalar (4) vasıtasıyla, plak gövdesinin (1) kemiğe bağlantısı 
sağlamlaştırılmaktadır. Şekil 2'de anlatılan plak gövdesi (1) ise daha mukavim kemik-plak gövdesi (1) bağlantılarının oluşturulması amacıyla kullanılmaktadır.

Şekil 3'e göre plak gövdesi (1) üzerinde 2 sıra halinde düzenli delikler (2) oluşturulmuştur. Plak gövdesi (1) üzerinde oluşturulan deliklerin yapısı, sayısı ve sıklıkları plak gövdesinin fiksasyon amacıyla kullanıldığı vücut parçasına göre değgişim göstermektedir.

Örneğin Şekil 3'te verilen plak gövdesi (1) üzerinde dar delikler (2) konumludur. Bu yapılanma ulna, radius ve fibula gibi daha ince kemiklerde kullanılmaya uygun yapıdadır.

Buluş dahilinde anlatılan çivi (4, 5), en az iki çivi kolu ları en az iki sıra halinde deliklerden (2) geçirilerek kemiğe sabitlenebilmektedir.

Şekil 4 ve Şekil 5'e göre çivi (5) "U” formunda tasarlanmı̧̧ iki çivi kolu bulunduran yapıdadır. "U" formunda tasarlanan çiviler (4) iki sıra halinde deliklerden (2) geçirilerek, kemiğe yerleştirilmektedir. Plak ve U çivilerin prototipi Şekil 6'da gösterilmiştir.

" $U$ " ve "T" formunda oluşturulan çivilerin (4, 5), çivi kolları deliklerden (2) geçerek kemiğe sabitlenmekte, çivi kollarına dikey konumlu olan " $U$ " form tabanı ise plak gövdesine (1) temas ederek montaj mukavemetine ters yönde destek verebilmektedir.

Şekil 5'te ise "T" formunda tasarlanmış bağımsız çiviler (5) gösterilmiştir. Örneğin Şekil 1'de gösterilen plak gövdesinin montajı için bu çivilerin (5) kullanılması durumunda, bir "U" formu oluşturmak için "T" formunda olan çiviler (5) deliklere (2) yerleştirilmektedir. bulunduran yapıları tarif etmektedir. Bu durumda çivi kol-

Çok sayıda çivi (5) kullanılarak oluşturulmuş bağlantı vasıtasıyla çok sayıda bağlantı noktası oluşturularak bağlantı mukavemeti arttırılmaktadır. Bu sayede uzun ve kemik derinliklerine inecek çivilerin (5) kullanımına gerek kalmadan mukavim bir bağlantı oluşturulmakta ve kemiğe minimum zarar verilmesi sağlanmaktadır.

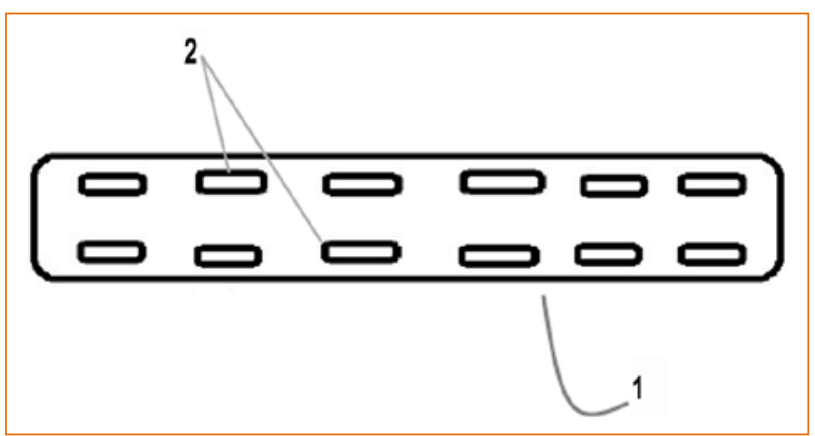

Şekil 1. Geniş delikli plağın üstten görünümü.

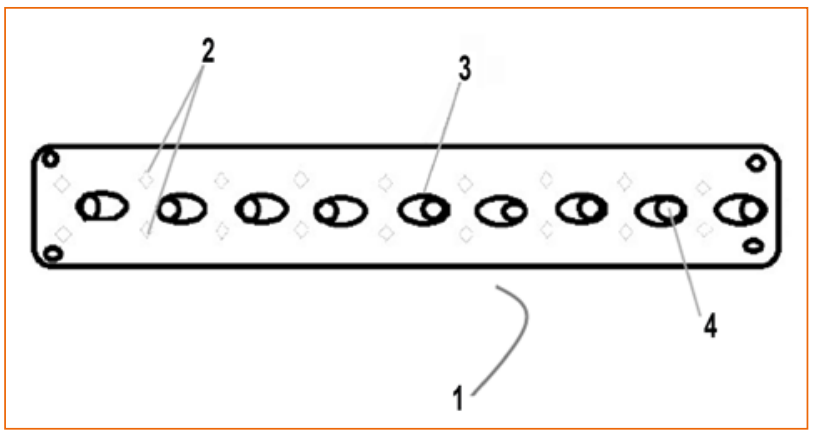

Şekil 2. Vidalı geniş delikli plağın üstten görünümü.

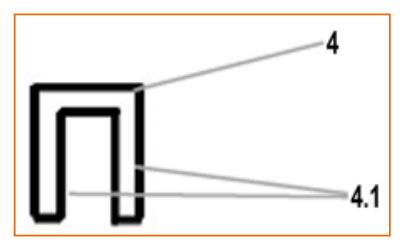

Şekil 4. "U" formunda çivinin kesit görünümü.

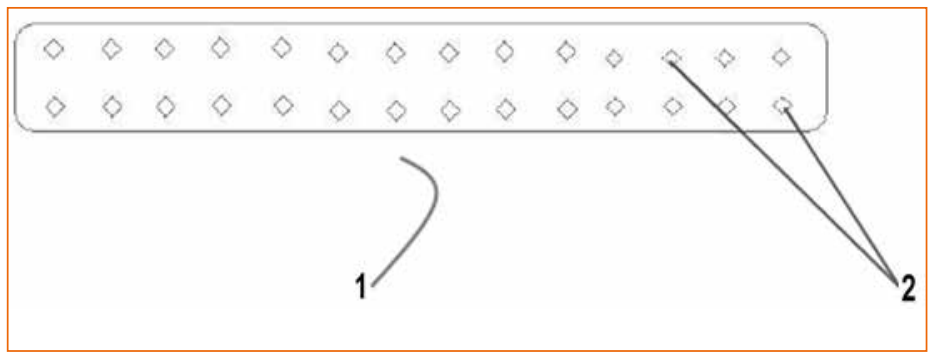

Şekil 3. Vidalı tespit yapabilen plağın üstten görünümü.

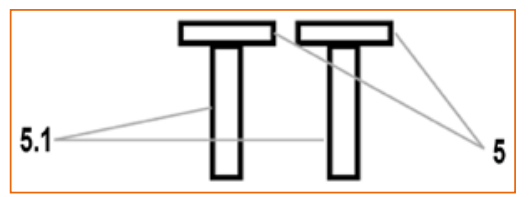

Şekil 5. "T" formunda çivinin kesit görünümü.

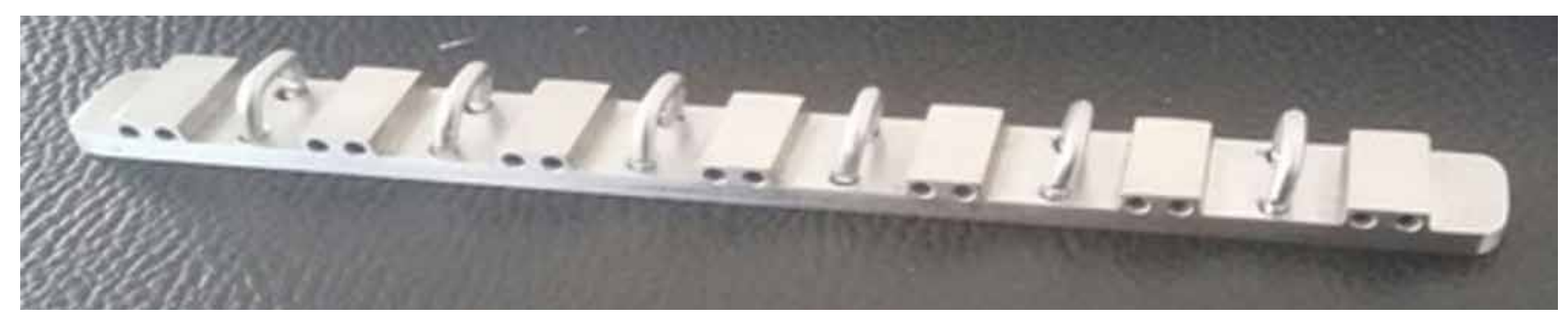

Şekil 6. "U” çivili ve serklaj teli uygulamalı plak. 


\section{İstemler}

1. Kemik kırıklarının tespitinde termal nekrozu engelleyerek, daha kuvvetli kırık fiksasyonu yapmaya uygun yapıda ortopedik bir implant olup özelliği; fiksasyon sırasında kemiğe tespit edilebilmesi amaciyla en az iki çivi kolu bulunan çivinin (4 ve 5) montajına uygun yapıda en az iki sıra halinde delikler (2) bulunduran plak gövdesinden (1) oluşmasıdır.

2. İstem 1'e göre ortopedik implant olup özelliğ; kanal formunda delikler (2) bulundurmasıdır.

3. İstem 1'e göre ortopedik implant olup özelliği; sıralı deliklerin (2) orta kısmında vida delikleri (3) bulundurmasıdır.
4. Istem 1'e göre ortopedik implant olup özelliği; iki çivi kolu bulunduran "U" formunda çivi (4) bulundurmasıdir.

5. Istem 1'e göre ortopedik implant olup özelliği; her bir çivi kolunu oluşturmak için " $T$ ” formunda bağımsı çiviler (5) bulundurmasıdır.

\section{KAYNAKLAR}

1. Çivili Plak Bulunduran Hibrit Bir İmplant Sistemi. T.C Marka ve Patent Kurumu. Patent Belge No: 2016/02293. https:// portal.turkpatent.gov.tr/anonim/arastirma/patent/detayli 